\title{
Konštantné hodnoty človečenstva v (slovenských) prózach Andreja Severíniho
}

\section{Constant Values of Humanity in (Slovak) Prose of Andrej Severíni}

Patrik Šenkár

(Komárno, Slovenská republika)

\begin{abstract}
Abstrakt:
Príspevok poukazuje na dôležitost̉ vzájomnej spolupráce na poli kultúrno-literárnych vztahov. Dôkazom toho je aj osobnost' Cornelia Barboricu, teda pseudonymom Andreja Severíniho, ktorý dlhé roky (od totalitného režimu až dodnes) konkrétnymi tvorivými činmi pomáha porozumeniu medzi Rumunmi a Slovákmi. Podstatou tohto textu je preto interpretačnou metódou poukázat na dôležitost týchto atribútov (aj) pomocou analýz jednotlivých - po slovensky publikovaných - krátkych próz tohto rodeného Rumuna.
\end{abstract}

\section{Klúčové slová:}

Andrej Severíni; Corneliu Barborică; interpretácia; národnosti; spolunažívanie

\section{Abstract:}

The contribution shows the importance of mutual cooperation in the field of cultural and literary relations. This is evidenced by Corneliu Barborică's personality (pseudonym Andrej Severíni), who for many years (from a totalitarian regime to this days) helps understanding between Romanians and Slovaks. The essence of this text is with interpretation methods to highlight the importance of these attributes and to analyse of individual-published in Slovak-short stories of this native Romanian.

\section{Key words:}

Andrej Severíni; Corneliu Barborică; interpretation; nationalities; coexistence 
„Bežne ludia hladajú viac istoty než pravdy. Lenže nový názor predpokladá pochybnost, a pochybnost'a spolu s ñou i nový názor na veci nemôžu vzniknút bez rozvoja individualít, diferencovanosti medzi členmi ludského spoločenstva, bez kritického ducha..."

Andrej Severíni, občianskym menom Corneliu Barborică, jeden z najvýznamnejších súčasných zahraničných slovakistov, krstný otec slovenských spisovatelov v Rumunsku, je dodnes významnou osobnost’ou slovakistiky v širšom chápaní. Ako spoluautor slovensko-rumunského slovníka, rumunsko-slovenského slovníka i vysokoškolskej učebnice slovenského jazyka kvalifikovane prispel k rozvoju slovenčiny vo svojej rodnej krajine. Jeho osobe sa pripisuje okolo pätnást̉ učebníc, čítaniek, gramatík a antológií, určených (najmä) pre jednotlivé stupne rumunskej vzdelávacej sústavy. $Z$ nášho aspektu nemôžeme nespomenút tú oblast̉ jeho mnohorakej činnosti, ktorá sa týka zásluh „,..o pozdvihnutie a popularizovanie umeleckej úrovne literárnej tvorby Slovákov v Rumunsku, ako aj jeho významný prínos $k$ posilneniu a sebauvedomeniu tamojšej slovenskej menšiny vôbec. “2 S Barboricovým menom je neodmyslitelne spojený aj vznik, zostavenie a (spolu)redigovanie dvanástich ročníkov zborníka Variácie $(1978$ - 1992). Bol patrónom, ale aj strážcom spisovnosti týchto zväzkov a podporovatelom beletristickej tvorby Slovákov z Rumunska ako vedomej súčasti celonárodnej slovenskej literatúry.

Corneliu Barborică je slavista, slovakista, vysokoškolský profesor, editor, redaktor, autor učebníc, antológií slovenskej literatúry, prekladatel', rodom Rumun. Narodil sa 5. 4. 1936 v Turnu Severine, kde prežil detstvo. Dostal sa na vysokú školu do Bukurešti a odtial na štúdium do Bratislavy a Prahy. Po skončení sa vrátil do vlasti a čoskoro sa zamestnal na univerzite v Bukurešti v sekcii slovenského jazyka a literatúry. Toto pracovisko sa mu stalo celoživotným pôsobiskom.

Do literatúry sa uviedol po slovensky písanou prózou vo Variáciách. Humoristické poviedky (v rumunčine) mu vychádzali v časopise Urzica (Žihlava), Literatorul, Luceafărul, Harababura a inde. Po rumunsky mu samostatne knižne vyšla detektívka Crima de la kilometrul 99 (Vražda na 99. kilometri, 1999), satirický román Colosul (Nadlak 200o), Poetul şi ciorile (Básnik a vrany, Nadlak 2002), Moartea lui Adrian Iacob (Smrt' Adriana Iacoba, Nadlak 2004) a v univerzitnom vydavatelstve v Bukurešti súbor krátkych próz Andrei Severini Călătorii imaginare (Imaginárne putovania, 2008). Po slovensky mu vyšli dve samostatné knihy. Prvá - Cintorín slonov a paralelné zrkadlá (Nadlak, 1996) pod pseudonymom Andrej Severíni - združuje beletristické texty, ktoré pôvodne vyšli v antológii Variácie tiež pod pseudonymom. Druhá - Pohlady,

1 BARBORICĂ, C.: Dobýjat’ sa zmyslu alebo o životodarnej sile pochybnosti. In: Pohlady, rozhlady a solilokviá. Nadlak: Vydavatel'stvo Kultúrnej a vedeckej spoločnosti Ivan Krasko, 1996, s. 98.

2 GÁFRIK, M.: Vzácny slovakista Corneliu Barborică (Andrej Severíni). In: Slováci v zahraničí 23. Martin: Matica slovenská, 2006, s. 76. 
rozhlady a solilokviá (Nadlak, 1996) - vyšla pod jeho vlastným menom a je výberom z jeho literárnovedných štúdií, úvah a veršov. V slovenskom preklade mu vyšli aj alegorické poviedky v Literárnom týždenníku na Slovensku (najmä v roku 1991). Próza s autobiografickými prvkami vyšla aj v slovenskom preklade Anny Rău-Lehotskej v Našich snahách plus (1/2012). Ako prekladatel’ sa zaslúžil aj o popularizáciu slovenskej a českej literatúry a kultúry v rumunskom prostredí viacerými prekladmi, za čo bol odmenený Cenou P. O. Hviezdoslava (1977), Národnou cenou (1991), Bielym dvojkrížom (2007), Poctami ministra kultúry (1996, 2003), Zlatou medailou Matice slovenskej (2006). Corneliu Barborică zomrel po dlhotrvajúcej chorobe v Bukurešti 11. mája 2017.

Prózu tohto autora možno označit za intelektuálnu, náročnú, ktorú je potrebné interpretovat aj metatextovo, t. j. hladat’ súvislosti v mimoliterárnej referenčnej osi i v odkazoch na literatúru a kultúru. Tým pôsobí už ako postmodernisticky ladený prototext.

Je dôležité uviest' „... politicky ladený podtón v Barboricovej tvorbe, ktorý môžeme vnímat aj ako základ jeho prínosu pre slovenské kultúrne bytie, ale aj ako cenný príspevok $k$ narúšaniu a odstrañovaniu istých občas sa objavujúcich slovenských ,komplexov'..."3 O knihe Cintorín slonov a paralelné zrkadlá sa slovenský kultúrny pracovník Kornel Földvári vyslovil, že „má klúčový význam pre dešifrovanie osobnosti Cornélia Barboricu“. Je to vlastne zväzok združujúci výber zo Severíniho prác uverejnených vo Variáciách. Prvá čast’ - Udalosti - združuje prozaické práce (poviedky). Zbierka hovorí o otázkach ludského bytia, o zložitých medziludských vztahoch, o hladaní autentických hodnôt v prevrátenom svete; skúma otázky mravnosti, legitimity moci, vnáša do sujetu aj problémy politického rázu v alegorickej podobe.

Vo všeobecnosti o tejto zbierke možno uviest', že jednotlivé texty sú pozoruhodné a čitatel'sky expresívne. V širšie koncipovanej humorne ladenej próze Cintorín slonov ide o navodenie smiechu a spochybnenie vžitých predstáv. Sloboda myslenia a kritický duch autora sa v nej prejavuje aj v zálube parodovat rôzne situácie totalitného obdobia.

Tieto prózy treba čítat̉ a chápat predovšetkým ako paraboly. V prípade samotnej prózy Cintorín slonov dej je akýmsi zhusteným a skráteným variantom pikaresknej epiky; pôsobí i dojmom paródie na dobrodružný román i oblúbené filmy s exotickou tematikou. $(\mathrm{Aj}) \mathrm{v}$ tejto próze ,... hlavným autorovým zámerom a cielom je navodit smiech i v mysli čitatela a vedno s ním sa zasmiat nad ludskou náturou. “4 Komickost̉” ako princíp je $\mathrm{v}$ nej často prítomná: autor takým princípom sa chce vyhnút priamemu moralizátorstvu, avšak sa pritom nechce zriect’ kritickosti. Smiech je vlastne

3 ANDRUŠKA, P.: Súčasní slovenskí spisovatelia z Rumunska. Nitra: Univerzita Konštantína Filozofa v Nitre, 2009, s. 117.

4 ANOCA, D. M.: Andrej Severíni - vyznávač smiechu a pochybností. In: Hladanie sférického priestoru. Nadlak: Vydavatel'stvo Kultúrnej a vedeckej spoločnosti Ivana Krasku, 1997, s. 154. 
spochybňovaním, je to priestor, kde možno oponovat', pochybovat'. Podla jeho mienky „... má pochybnost', pochybovanie životodarnú silu, pomáha dobyt sa $k$ zmyslu vecí. ${ }^{5}$ Pri využití smiechu v jeho epickej próze sa vyskytujú navonok triviálne témy a konflikty. Pozorný čitatel si uvedomí, že tu je čosi zašifrované, čosi, čo je skutočným odkazom týchto próz. $\mathrm{V}$ tom spočíva ich charakter podobenstva. Autor text zašifrúva, aby ho pred čitatelom odšifroval, alebo aspoň podal návod, ako ho treba chápat'.

Dojímavý príbeh o starom slonovi Bimbovi nesie v sebe hlbokú filozofickú myšlienku príchodu na svet a odchodu každého živého stvorenia z tohto sveta. Autor uvádza v sujete (kladné až ideálne) životné podmienky tohto zvierata v zoologickej záhrade. Kontrastívne poukazuje na jeho obrovskú silu, ktorú však zo slušnosti nepoužíva. Vyzdvihuje sa teda jeho určitá socializácia v danom prostredí a z toho vyplývajúca oblúbenost̉ najmä u návštevníkov. Zdôrazňuje sa pritom potreba vlastného životného priestoru, okorenená vnútorným zápasom s myšlienkami. Táto cesta životom zvierata i človeka slúži preto, aby každý bol „... mravne očistený, pod vlastným svedomím ospravedlnený a duševne vyrovnaný... ${ }^{\text {6 }}$ Do popredia sa dostáva plynutie rokov život slona i jeho další osud po priestupku proti zákonom mravnosti. Autor opisuje jeho dobrodružnú mladost', pomoc a solidaritu pri záchrane ludského života v dalekej krajine. Postupne sa retrospektívnym rozprávaním čitatelia dozvedajú o jeho ceste z chudobnej krajiny bez slobody, lásky a jedla až za ohradu zoologickej záhrady s adekvátnymi vymoženostami. Dramatickým vyvrcholením príbehu je porušenie božieho príkazu nehanebnej krádeže, ktorá je však pre citlivého človeka ospravedlnitelná empatickostou. Dôležitost̉ duševnej energie a sily vôle pomáha teda každému živému tvorovi dosiahnut svoj ciel.

Dramatickým vyvrcholením príbehu je zmiznutie Bimba pod rúškom noci. Autor ten čas hodnotí ako obdobie, ked’ sa na zemi všetko stane malým a bezvýznamným. Detektívne pátranie všemožnými spôsobmi po slonovi aj vdaka metódam súčasnosti (novinár bažiaci po škandále, uvádzanie fotografie slona namiesto signálu v televízii a pod.) však nevedie $\mathrm{k}$ vytúženému cielu. Tajomnost’ príbehu na báze akéhosi vševediaceho čitatela podopiera vysvetlujúci list „neznámeho“ záchrancu, pomocou ktorého sa Bimbo dostane na symbolické, ale aj konkrétne miesto svojho posledného pôsobiska. Dôležité je teda splnenie poslednej túžby každého, ved’onen výraz zmierenia sa s osudom je dozaista hrejivým pocitom dobrosrdečného človeka. Alegorické miesto, ako je cintorín slonov v húštinách Afriky, kde „... sa poberajú pred bližiacim sa skonom

5 Tamtiež, s. 155 .

6 SEVERÍNI, A.: Cintorín slonov a paralelné zrkadlá. Nadlak: Kultúrna a vedecká spoločnost̉ Ivana Krasku, 1995, s. 9. 
tieto nádherné zvieratá..."7, vie chápat iba človek poetický, vlúdny, citlivý - teda $\mathrm{v}$ určitom slova zmysle básnik.

V tomto zmysle vyznieva aj próza Nezvyklá udalost’ o invázii žralokov, v ktorej autor odhalil dobovú nezdravú atmosféru. Žralok je v tejto Barboricovej próze symbolom dravého systému, ktorý oberá ludí o dušu a pokoj. V nadčasových súvislostiach však stelesňuje prekážku, ktorú treba odstránit. Intertextuálnost̉ a interkultúrnost’ sa tu prejavuje ako jeden zo zdrojov humoru. Príbeh o velkej senzácii pri pobúrenosti celej župy je základom sujetu dalšieho textu Andreja Severíniho. On sám ako autorský subjekt je integrálnou súčasţou celého textu: dáva čitatelom impulzy, myšlienky, návnaky o spôsobe nazerania na text: „Lebo autor vám nemusí všetko prezradit'. Dnešný autor prišiel na to, že povedat všetko, i to, čo sám nevie, je hlúposṫ. Čitatelovi sa všetko povie - a potom čo? Taký čitatel' spohodlnie a osprostie... Autor je tiež čitatelom, ktorý sa pustil do písania preto, lebo sám chce čítat... O zmysel diela treba bojovat' - to je nesporné. “8 $\mathrm{V}$ autorovom texte zohráva dôležitú úlohu v širšom chápaní metatextovost̉ a alúzia. Odráža sa však od reálneho sveta, ktorý chápe ako nespravodlivý (až priam nezmyselný). Rozprávkovost’ sa vynára ako sprievodné ovzdušie sujetu (nepokoj, tušenie, podozrenie). Počiatočná absurdnost', pripomínajúca až hororovost', je uvedená zmiznutím muža - manžela. Nezmyselné výmysly o možných príčinách jeho zmiznutia sú na hranici akceptovatelnej konotatívnosti aj pre skúsenejších čitatelov (možno ho zožrali vlci aj s kostami, možno ho zabila čertica Trnková so svojím milencom...). Tragikomicky vyznie fakt o kúpe náhrobného kamenného pomníka s nápisom o zožratí nebohého nenažratými vlkmi (pri absencii tela mútveho). Ako deus ex machina sa náhle objaví postava muža (manžela) a nastáva postupné vysvetlenie toho, prečo vlastne zmizol (radšej zinscenoval vlastnú smrt̉ pomocou slepačej krvi, ako by mal zniest̉ to strašné stvorenie - manželku).

Podobne zaujímavý až morbídny prípad na rovinatej krajine, na brehu riek s víbami pri kukuričnom poli opísal autor $\mathrm{v}$ dalšom texte dialogickou formou. Jednotlivé repliky sú humorné, svieže, s nádychom špecifického koloritu a maximálneho využitia komickosti. Rozhovor starca s trpaslíkom o vlastných životných osudoch priam „vtiahne“ vnímavého čitatela do príbehu (prečo neukradol viac pálenky, čo žerú ludia počas dňa, prečo deti utiekli z domu a pod). Tieto repliky sú v konečnom dôsledku upriamené na až sarkastickú tému vztahu $\mathrm{k}$ manželke. Žena sa v nej vykresluje ako panovačná zmija, ktorá doslovne zožerie telo a najmä dušu muža. Postupnými, akoby vyšetrovacími otázkami, sa poukazuje na dobový matriarchát v danom regióne, v ktorom sú nebezpečné aj samotné otázky. Je to určitý znak nevraživosti doby, v ktorej nikto neverí nikomu, i keby hovoril pravdu. Jedinou útechou

7 Tamtiež, s. 16.

8 Tamtiež, s. 19-20. 
moderného Adama Krta je teda jeho útočisko v krčme, ktorá mu poskytne určitý azyl pred trápením a pekelnými mukami svojej ženy. Vztah muža a ženy je vykreslený s nepreklenutelnou priepastou, dvoma proti sebe stojacimi svetmi (idealistickým mužským, materialistickým - ženským). V očiach ženy je dôležité mat’ auto (a vozit sa na ňom ako tá dáma Ananásová). Toto typizovanie dobových túžob niektorých žien je okorenené aj klebetami, hundraním a strkaním nosa do cudzej kapusty. Do tohto sporu sa nemôžu vmiešat cudzí, ba ani deti, ktoré ,... majú poslúchat svojich rodičov. fe to ich svätá povinnost. “9 Manželské pletky, urážky, poúčania nemajú konca kraja. Zo strany ženy zaznie kritika (okrem muža) aj na knihy a noviny: „Môj muž ma chce poúčat. A z kníh! Vo vlastnej kotrbe nič nemá. Po cudzie rozumy chodí. Vlastný nemá a môj mu nestači. " ${ }^{10} \mathrm{~V}$ tomto svete intríg a nepokojov ludia dávajú viac na cudzie reči, ako na to, čo by mali vlastne oni osobne hovorit. V takomto svete sa symbolicky i fyzicky objavujú žraloci, likvidátori ludí. Zmiznutie druhého muža pridáva na vážnosti situácie. Existuje aj myšlienka o zbavení sa nevinných ludí ich hodením žralokovi ako pokrmu. Aluzívne (opät až morbídne) znie fakt, že v dedine po všetkých (azda) mŕtvych „... zostali topánky na brehu pod vŕbou. Niekto mal výborný nápad: pozbierat’ všetky pozostalé topánky a zorganizovat múzeum. Tak aj urobili. " ${ }^{11}$ Zaujímavým mementom je vnímanie správania ludí v okolí: niekto písal srdcervúce verše, niekto ozdobil Múzeum zosnulých na oltári žraloka. Po neštastnej situácii „uhynutia“ ludí sa však musia dedinčania zjednotit a na báze (autorovej) podpory vymyslieł plán na prežitie. V nastolenej otázke sa, samozrejme, malá dedina rozpadla na dva tábory. Tým autor vyjadril nejednotnost ludí. Pri rôznych variantoch riešenia sa opisujú najmä komické možnosti, ktoré však nesú v sebe egoizmus a bezohladnost': pekne poprosit žraloka o zmenu revíru; vyslovit žralokovi prosbu, aby išiel o kilometer dalej do zaludnenej dediny - nech majú oni škodu a pod. Rozprávkový motív vystrojenia poslov k žralokovi s rôznymi neludskými návrhmi tiež charakterizuje častú absenciu chrbtovej kosti u človeka. Je až absurdné, že práve žralok (ako vševediaca vyššia inštancia) opisuje realitu ludí z mäsa a kostí: „Žeriete sa medzi sebou. Ako hyeny... Robíte zo seba hlúpych. Zbytočne. No hlúpi ste."12

Žralok ako symbol moci ludské duše potrebuje zaživa. Tento faustovský motív, z ktorého by sa mali učit aj dedinčania, opät vychádza nazmar. L’udia sú nepoučitelní, materiálne (telo) pre nich znamená ovela viac ako ideálne (duša): „Doparoma aj $s$ dušou... Len nech nám zdravie slúži... Nakoniec, načo je človekovi duša?... Na nič."13

\footnotetext{
9 Tamtiež, s. 34 .

10 Tamtiež, s. 36.

11 Tamtiež, s. 41.

12 Tamtiež, s. 46.

13 Tamtiež, s. 47-48.
} 
Zaujímavým (až odstrašujúcim) príkladom je služba voči (ne)identifikovatelnej moci. Z tohto aspektu autor uvádza neblahú situáciu umelcov, ktorí v pozadí existencie personifikovaného žraloka musia držał jazyk za zubami, písat hymny na neho a poznat jazykové šablóny. Tento postoj však podla autora koniec koncov vedie do temnoty a záhuby ludskej duše. Vyvrcholením (vymyslenej?) nezmyselnosti doby je cyklické organizovanie žraločích slávností. Ich alúzia na vel'ké manifestácie (ne)demokratického zriadenia zdôrazňujú absurdnost̉ doby. Ozajstné ludské charaktery sa však vykryštalizujú pri zmene spoločenského systému a postupne vytvárajú opozíciu. V dôsledku novovzniknutej velkej patálie sa však autor vyslovuje o nepolepšitelnosti človeka, ktorý ako bytost' ,... v spoločnosti ludí nevie žit. Zviera velmi podivné. Ani v stáde, ani mimo stáda. Mimo stáda sa bojí samoty a v stáde sa bojí toho druhého. "14 Ludí kazí najmä žraločia maska a pseudopocit dočasného blahobytu. Dôležitý je len život - a to ludský, obsažný. Do protikladu sa teda stavia život a smrt', zem a cintorín. Rozmýšlajúci človek však utečie: hladá štastie, kde môže žit bez masky, bez žraloka. A tam je podstata a zmysel existencie života každého z nás...

V minipríbehoch Šest krátkych lúbostných románov vo dvoch častiach s epilógom odhaluje šedivost̉ ludskej existencie a mravný úpadok konzumnej spoločnosti. Exemplifikačný príklad stroskotania manželstva po psychickej odcudzenosti opisuje autor v krátkych útržkovitých textoch, ktoré znejú ako denotatívne konštatovania. Poukazuje v nich na oblúkovitost' a sínusoidný charakter vztahu a jeho vyhorenie (slušný pár so slušnými rodičmi - svadba - postupné odcudzenie pre nedostatok času na seba - rozvod). Retrospektívne pohlady na minulost’ však nevedú k cielu a znovuobjaveniu stratených ilúzií. Taký je kolobeh života.

Próza Prečo sa Jano Jandál dostal do neštastia odkrýva zvrátený spoločenský systém, ktorý má dosah aj na súkromie malého človeka. Ironizuje apatiu ludí a ich nevôlu k činom. Spochybňovanie je teda základný princíp jeho próz. Postupným demaskovaním faktov a súvislostí vyvoláva dezilúziu, trpkú iróniu u zrelého človeka. Pritom sa vysmieva ludským (ne)cnostiam i literárnym konvenciám. V próze sa vyskytujú narážky na nedostatok klincov, v čom spočíva aj vyvrcholenie deja a rozuzlenie: pre nedostatok klincov nemôže hrdina opravit plot, z čoho má pokuty, čo žena nemôže strpiet'. Autor sa zaoberá aj jednoduchými nerestami a nedostatkami ludí a spoločnosti. Odkrýva spoločenský zvrátený systém, ktorý má dosah aj na súkromie ludí, ale vysmieva sa aj nedostatku ich aktívnosti. Tematika rozvodu je prítomná aj v tomto texte, v ktorom centrálnu úlohu hrá opät bezcitná žena - manželka. Autor zase prízvukuje absenciu vzájomnej komunikácie, mlčanie, ktoré začne pohýnat aj duševné balvany. Submisívnost̉ muža a komickost’ celej situácie vyznie v tom, že Jano s plačom prosí svoju ženu, aby sa s ním nerozviedla - s ním, vedúcim úradu na

14 Tamtiež, s. 56. 
utuženie rodinného života a zabezpečenie správneho prírastku obyvatelstva. Dôležité je však zachovat si ludskú dôstojnost̉ na báze partnerskej rovnocennosti.

Poviedka Čo sa stalo Azorovi, dôverčivému psovi, alebo ako môže niekto zaplatit životom za radost’ vykresluje ironickú slepú dôveru i cenu, ktorú treba zaplatił za poznanie. Motivicky čerpá zo sveta detí s nádychom poetizácie. Autorovi v nej ide o zobrazenie medziludských vztahov i neblahých zmien v živote; je to dojímavá parabola o dospievaní, priatel'stve a poznaní. Určitým „odlahčením“ príbehu je prázdninový sled udalostí mladého chlapca a jeho psa Azora. Do ich prázdninového života zasiahne ako blesk z jasného neba povinné opätovné ranné vstávanie, lebo sa ide na malú dovolenku. Do kontrastu sa dáva mestské a dedinské prostredie, charakterizované panelákom a na druhej strane dvorom s čerešňou a marhulami. Autor prízvukuje, že je dôležité (a osožné) nazbierat životnú energiu a skúsenosti. $\mathrm{V}$ dedinskom prostredí, ktoré priam vábi na prechádzku, je záslužné naučit sa vítat každý nový deň. Preto až pietne vyznie správanie malého Janka, ktorý „... zavinšoval slnku, modrému nebu, čiernemu drozdovi, ktorý si radostne jódloval v ranných lúčoch, hrdličkám, ktoré sa dívali nañ $z$ vysokého konára. "15 Autor však vyvažuje tieto statické opisy ideálneho mikroprostredia aluzívnymi mikropríbehmi (napríklad ako sa sused staral o svoje hrdličky, aby ich potom mohol zjest’ ako pochútky). V texte je dôležité kamarátstvo dietata so psom a nelogické správanie niektorých dospelých egoistov (ja som Rumun, beloch a ty nie). L’udský svet sa dáva do kontrastu so zvieracím, kde suka aj biely foxteriér sú prototypmi starostlivých a svedomitých spoločníkov. Nezmyselná smrt’ foxteriéra Azora a zmiznutie mladej suky zvýrazňuje dramatickost', nevyhnutnost' osudovosti a prirodzenú túžbu po slobode. Pars pro toto však ,... zostala po nej spomienka. A večer pri ohni priadli z jej života pekné rozprávky. “16 Tie „neludsky ludské“ rozprávky však musia byt vždy srdečné, hlásajúce dobrotu, nádej a odvekú túžbu po spravodlivosti. Ved paralelné zrkadlá nám koniec koncov dávajú náš obraz iba pre nás...

Príkladom literárneho textu a myšlienok Andreja Severíniho je jeho poviedka s názvom Ktože vie prečo. Prostredie železničnej stanice, meškanie vlakov a motanica, ked „všetko je možné“, symbolizuje zbytočnost̉ ludskej existencie v pozadí (ne)normálneho plynutia času. Dôležité je poznat seba i okolitý svet - teda krátkoi dlhodobé ludské známosti. Autor do tohto prostredia vkladá nevšedný, ale pestrý dialóg dvoch ludí čakajúcich na vlak, ktorí vo forme rozhovoru typu Lasica - Satinský deklarujú až absurditu súdobej spoločnosti v aktuálnych realitách danej doby. Ikonou ludského snaženia je stavba vlastného domu, teda dôležitý význam práce, vdaka ktorej je človek ochotný obetovat aj neprirodzené skutočnosti (dostał’ sa do väzenia, za

15 Tamtiež, s. 77.

16 Tamtiež, s. 81. 
pôžičku ručit mramorovou hrobkou svojej svokry). Na báze toho je signifikantné, až prevrátene domysleniahodné, že „,... žijeme v dobe všetkých možností. Všetky dvere sú nám otvorené. “17 Postupná redukcia životného priestoru (stačí len jediná izba) svedčí o postupnom zúžení možností človeka, ktoré autor vypointuje dnes už formou smiechu cez slzy (deti pomreli od hladu a zimy, žena je smrtelne chorá na plúca). Odvolávanie sa na základné ludské práva (garantované ústavou) je aj v tomto spletitom svete istý racionálny bod, ktorý sa však postupne vzdaluje zväčšujúcim sa zásahom vyššej moci do mikropriestoru jednotlivca. Čakanie na vlak je potvrdením absurdity vo vzţahu človek - vyššia moc, pri ktorom autor zdôrazňuje aj určitú ludskú zištnost̉ čakáme vždy na príchod a na odchod nemyslíme. Arogancia moci sa tu vykryštalizuje symbolicky: „O dopravu sa stará mnoho pánov. Ked’ nevieš, na ktorú osobu sa máš obrátit, múdrejšie bude sa vôbec neobrátit. Logické, nie?"18 Tento (až absurdný) kolobeh určitého čakania na Godota (resp. na vlak, ktorý symbolicky aj fyzicky vlastne ušiel) deklaruje popletenost človeka v tejto anarchii a jeho jedinú možnost': dlhý čas čakania a dúfania. Autor sa však vyslovuje s nádejou na zlepšenie tohto stavu v širokospektrálnej budúcnosti, kde vidí jediný zmysel našej ludskej existencie a bytia, ved: ,...ak ho my nechytime, myslím ten vlak, tak ho chytia naše deti. Alebo naši vnuci alebo vnuci našich vnukov. Raz musí príst." 19

\section{Literatúra:}

ANOCA, D. M.: Andrej Severíni - vyznávač smiechu a pochybností. In: Hladanie sférického priestoru. Nadlak: Vydavatel'stvo Kultúrnej a vedeckej spoločnosti Ivana Krasku, 1997, s. $152-167$.

ANDRUŠKA, P.: Súčasní slovenskí spisovatelia z Rumunska. Nitra: Univerzita Konštantína Filozofa v Nitre, 2009.

BARBORICĂ, C.: Dobýjat'sa zmyslu alebo o životodarnej sile pochybnosti. In: Pohlady, rozhlady a solilokviá. Nadlak: Vydavatel'stvo Kultúrnej a vedeckej spoločnosti Ivan Krasko, 1996.

GÁFRIK, M.: Vzácny slovakista Corneliu Barborică (Andrej Severíni). In: Slováci v zahraničí 23. Martin: Matica slovenská, 2006, s. $75-81$.

17 SEVERÍNI, A.: Ktože vie prečo. In: KMEŤOVÁ, E. D., MÓŤOVSKÁ, A. (eds): Antológia slovenskej literatúry. Zväzok IV. Nadlak: Vydavatel'stvo Ivan Krasko, 2005, s. 463.

18 Tamtiež, s. 466.

19 Tamtiež, s. 465 . 
SEVERÍNI, A.: Cintorín slonov a paralelné zrkadlá. Nadlak: Kultúrna a vedecká spoločnosṫ Ivana Krasku, 1995.

SEVERÍNI, A.: Ktože vie prečo. In: KMEŤOVÁ, E. D., MÓŤOVSKÁ, A. (eds): Antológia slovenskej literatúry. Zväzok IV. Nadlak: Vydavatelstvo Ivan Krasko, 2005, s. $462-467$.

\section{About the author Patrik Šenkár \\ J. Selye University, Faculty of Education, Department of Slovak Language and Literaure, Komárno, Slovak Republic \\ senkarp@ujs.sk}

